\title{
Potential application of coastal biofilm-coated gravel particles for treating oily waste
}

\author{
S. S. Radwan*, R. H. Al-Hasan \\ Department of Biological Sciences, Faculty of Science, Kuwait University, PO Box 5969, Safat 13060, Kuwait
}

\begin{abstract}
This paper reports on hydrocarbon-degrading microbial consortia immobilized in biofilms on gravel particles in the intertidal zone of the Arabian Gulf coast. These microorganisms contribute to the self-cleaning of the coasts and, in addition, could potentially be used for cleaning oily industrial waste before its disposal in the open environment. Each gravel particle was found coated with about $100 \mathrm{mg}$ biofilm of blue-green biomass. The predominant phototrophs were the cyanobacteria Dermocarpella and to a lesser degree Lyngbya sp. The most dominant hydrocarbondegrading bacterium in this consortium was Acinetobacter calcoaceticus; minor bacteria included Micrococcus and nocardioforms. The biofilm-coated gravel particles were used in 5 successive cycles of purification of oily sea water. This immobilized microflora was efficient during all cycles in hydrocarbon consumption. In contrast, bacteria adhering to biomass-uncoated gravel particles brought about hydrocarbon degradation in the first few cycles, but then gradually lost their cleaning potential, apparently due to their successive washing out from the particles during successive cycles.
\end{abstract}

KEY WORDS: Biofilm · Cyanobacteria $\cdot$ Hydrocarbon degradation · Oily waste treatment

\section{INTRODUCTION}

The deliberate release of crude oil into the Arabian Gulf by the Iraqi forces during the occupation of Kuwait, 2 August 1990 to 26 February 1991, resulted in the pollution of the intertidal zones along the western Gulf coast. Shortly thereafter massive growth of bluegreen mats occurred on the top of coastal oil sediments (Sorkhoh et al. 1992). The microbiological analysis of these mats revealed that they consisted of the filamentous cyanobacteria Phormedium and Microcoleus, which were immobilizing large numbers of hydrocarbon utilizing microorganisms (Al-Hasan et al. 1994, 1998, Sorkhoh et al. 1992). Each gram of the mat was found to contain several million hydrocarbon-utilizing bacteria belonging predominantly to the group of nocardioforms, particularly the genus Rhodococcus. These bacteria could utilize a wide scope of $n$-alkanes, ranging from $\mathrm{C}_{9}$ to $\mathrm{C}_{38}$, and aromatic hydrocarbons as sole sources of carbon and energy. Evidence was also provided that the cyanobacteria in the mats play an

*E-mail: radwan@kuc01.kuniv.edu.kw active role in hydrocarbon biodegradation (see the above references).

These microbial mats were considered the first sign of self-cleaning of the polluted Gulf coasts. In a later study it was found that the Arabian Gulf coast has a much higher potential for hydrocarbon biodegradation than the water body (Radwan et al. 1999). In this paper we report on another novel biofilm association immobilized on gravel particles from the intertidal zone of the Kuwaiti Gulf coast. This immobilized association contributes to the self-cleaning of this environment and, in addition, could potentially be of technical value in cleaning oily waste prior to disposal at sea.

\section{MATERIALS AND METHODS}

Sampling. Gravel particles coated with microbial biofilms were observed on and collected from the Subiah beach, on the northern part of the Kuwaiti coast, opposite the Warba and Bubian islands. Their mean particle diameter was 2 to $3 \mathrm{~cm}$. While the biofilm-free particles were white to grey in color, the biofilm-coated particles had aquired the typical blue- 
green color of the cyanobacteria. Biofilm-coated and -uncoated gravel particles were collected in sterile plastic bags, transported to the laboratory and studied within $24 \mathrm{~h}$.

Microbiological analysis. The blue-green biofilmcoating of gravel particles was scraped off and suspended in sea water. The phototrophic organisms were then examined microscopically and identified.

To count oil-utilizing bacteria the standard plate method was used. Immobilized microorganisms were first suspended in sterile sea water by homogenizing microbial mat samples scraped off from the particles. A solid inorganic medium containing $1 \%(\mathrm{w} / \mathrm{v})$ weathered crude oil as a sole source of carbon and energy was used (Sorkhoh et al. 1990). This inorganic medium had the following composition $\left(\mathrm{l}^{-1}\right): 30 \mathrm{~g} \mathrm{NaCl}, 0.85 \mathrm{~g}$ $\mathrm{NaNO}_{3}, 0.56 \mathrm{~g} \mathrm{KH}_{2} \mathrm{PO}_{4}, 0.86 \mathrm{~g} \mathrm{Na}_{2} \mathrm{HPO}_{4}, 0.17 \mathrm{~g} \mathrm{NaNO}_{3}$, $0.56 \mathrm{~g} \mathrm{KH}_{2} \mathrm{PO}_{4} \cdot 7 \mathrm{H}_{2} \mathrm{O}, 0.007 \mathrm{~g} \mathrm{CaCl}_{2} \cdot \mathrm{H}_{2} \mathrm{O}, 0.004 \mathrm{~g} \mathrm{Fe}$ (III) EDTA and trace element solution $(0.25 \mathrm{ml})$ consisting $\left(\mathrm{l}^{-1}\right)$ of: $2.32 \mathrm{~g} \mathrm{ZnSO}_{4} \cdot 7 \mathrm{H}_{2} \mathrm{O}, 1.7 \mathrm{~g} \mathrm{MnSO}_{4} \cdot 4 \mathrm{H}_{2} \mathrm{O}, 0.56 \mathrm{~g}$ $\mathrm{KBO}_{3}, 1.0 \mathrm{~g} \mathrm{CuSO} \cdot 5 \mathrm{H}_{2} \mathrm{O}, 0.39 \mathrm{~g} \mathrm{Na}_{2} \mathrm{MoO}_{4} \cdot 2 \mathrm{H}_{2} \mathrm{O}$, $0.66 \mathrm{~g} \mathrm{KI}, 1.0 \mathrm{~g}$ EDTA, $0.4 \mathrm{~g} \mathrm{FeSO}_{4} \cdot 7 \mathrm{H}_{2} \mathrm{O}, 0.004 \mathrm{~g}$ $\mathrm{NiCl}_{2} \cdot 6 \mathrm{H}_{2} \mathrm{O}, 15.0 \mathrm{~g}$ agar, $\mathrm{pH} 7$. The plates were incubated at $30^{\circ} \mathrm{C}$. Bacteria that grew on this specific medium were considered to be hydrocarbon-utilizing microorganisms and their hydrocarbon degradation potential was confirmed by quantitatively measuring the proportions of $n$-hexadecane they consumed from their media by gas liquid chromatography (GLC) (see later).

After counting the total and individual microorganisms, representative strains were isolated on the same medium and identified by consulting pertinent keys and comparing the unknown isolates with previously identified strains in our collection.

Measurement of cleaning potential. An experiment was carried out to study the potential of the microbial consortia immobilized on gravel particles for selfcleaning of the coast and cleaning of oily industrial waste. Sea water from the Gulf was artificially polluted with $2 \%(\mathrm{w} / \mathrm{v})$ crude oil and $0.15 \%(\mathrm{w} / \mathrm{v})$ of $\mathrm{KNO}_{3}$ was added as a nitrogen source for the microorganisms. The polluted water was dispensed into 11 Roux bottles, each receiving $100 \mathrm{ml}$ water. Each bottle received further 12 to 13 biofilm-coated gravel particles weighing $160 \mathrm{~g}$. Control bottles received equal aliquots of uncoated gravel particles. The flasks were incubated on a shaking electric rotary, $60 \mathrm{rpm}$, at room temperature (about $25^{\circ} \mathrm{C}$ ), under alternating day and night conditions. After $10 \mathrm{~d}$ (Cycle I) the gravel particles of each bottle were aseptically transferred into another $100 \mathrm{ml}$ aliquot of oily sea water and shaken for another $10 \mathrm{~d}$ (Cycle II). The process was repeated until we had a total of 5 cycles using the same lot of gravel particles. At the end of each cycle the oily sea water was collected and used for: (1) counting and isolating oil-utilizing microorganisms as described above, and (2) recovery of residual oil by thrice extraction with diethyl ether. After volatilizing the solvent the crude oil was weighed and the percent consumption calculated.

Analysis of constituent hydrocarbons. Oil (or oil extract) aliquots were fractionated by preparative thin layer chromatography (TLC) on silicic acid plates using hexane-diethyl ether, 90:10, by volume as a developing solvent (Mangold \& Malins 1960). The TLC pure hydrocarbon fractions close to the chromatogram fronts were quantitatively recovered from the sorbent (Kates 1972) and analyzed by GLC. For this purpose we used a Chromopack CP-9000 instrument equipped with a flame ionization detector, a WCOT fused silica capillary column and a temperature program of 150 to $310^{\circ} \mathrm{C}$, raising the temperature $20^{\circ} \mathrm{C} \mathrm{min}{ }^{-1}$ starting from $182^{\circ} \mathrm{C}$. The total peak areas for the hydrocarbons, which ranged from $\mathrm{C}_{9}$ to $\mathrm{C}_{36}$, were taken as quantitative measures of their concentrations.

\section{RESULTS}

During successive trips it was observed that gravel particles in the intertidal zone of the Kuwaiti coast of the Arabian Gulf started to aquire a deep blue-green color in March and October of each year. Microscopic examination revealed that those particles were coated with microbial consortia containing both cyanobacteria and organotrophic bacteria. It has been calculated that each particle was coated with about $100 \mathrm{mg}$ of that biofilm. The predominant cyanobacterium on gravel particles collected in October 1999 was the genus Dermocarpella. In addition filaments of Lyngbya sp. were found in the biomass coats of the particles. When some particles were covered with sea water in a petri dish and kept under room conditions for $6 \mathrm{wk}$, the biofilm coat which became thicker was found to consist predominantly of Lyngbya sp.

Table 1 shows the number of oil-utilizing bacteria associated with biofilm-coated and -uncoated gravel particles at the start and at the end of the 5 cleaning cycles. Shaking the uncoated gravel particles in oily sea water for $15 \mathrm{~min}$ resulted in almost all the adhering bacteria becoming suspended in the water. In contrast, subjecting biofilm-coated particles to the same treatment resulted in the release of only about one-third of the total bacteria into the water, leaving about twothirds of the total bacteria still firmly adhering to the particles. The total numbers of oil-utilizing bacteria were higher on biofilm-coated than on -uncoated particles.

The values in Table 1 show further that the numbers of oil-utilizing bacteria at the end of the 5 cleaning 
Table 1. Total numbers (in millions) of oil-utilizing bacteria in each $100 \mathrm{ml}$ batch at the start and after the end of 5 cleaning cycles. Data are means of 3 determinations, \pm standard deviation. Few $=<10^{2}$ cells per particle

\begin{tabular}{|lcccc|}
\hline & \multicolumn{2}{c}{ At the start } & \multicolumn{2}{c|}{ At the end } \\
& $\begin{array}{c}\text { Uncoated } \\
\text { gravel }\end{array}$ & $\begin{array}{c}\text { Coated } \\
\text { gravel }\end{array}$ & $\begin{array}{c}\text { Uncoated } \\
\text { gravel }\end{array}$ & $\begin{array}{c}\text { Coated } \\
\text { gravel }\end{array}$ \\
\hline Immobilized & Few $^{\mathrm{a}}$ & $83.4^{\mathrm{a}} \pm 3.8$ & Few & $16.6 \pm 1.3$ \\
Free & $90.1^{\mathrm{b}} \pm 5.3$ & $47.8^{\mathrm{b}} \pm 2.1$ & $0.2 \pm 0.01$ & $0.4 \pm 0.02$ \\
Total & 90.1 & 131.2 & 0.2 & 17.0 \\
& \multicolumn{4}{c}{} \\
a On the gravel particles after shaking for 15 min \\
' In the oily sea water after shaking for 15 min \\
\hline
\end{tabular}

Table 2. Total numbers (in millions) of oil-utilizing bacteria freely suspended in each $100 \mathrm{ml}$ batch of sea water at the end of 4 cleaning cycles. Data are means of 3 determinations \pm standard deviation

\begin{tabular}{|lcc|}
\hline Cycle & Uncoated gravel & Coated gravel \\
\hline I & $224.3 \pm 5.1$ & $101.5 \pm 3.2$ \\
II & $40.8 \pm 0.9$ & $212.2 \pm 7.3$ \\
III & $35.4 \pm 1.1$ & $40.4 \pm 1.5$ \\
IV & $22.2 \pm 0.7$ & $31.5 \pm 1.2$ \\
\hline
\end{tabular}

Table 3. Hydrocarbon attenuation in oily sea water containing uncoated and biofilm-coated gravel particles. Data are means of 3 determinations \pm standard deviation

\begin{tabular}{|c|c|c|c|c|}
\hline \multirow[t]{3}{*}{ Cycle } & \multicolumn{4}{|c|}{$\%$ consumption } \\
\hline & \multicolumn{2}{|c|}{ Uncoated gravel } & \multicolumn{2}{|c|}{ Coated gravel } \\
\hline & $\begin{array}{l}\text { Total } \\
\text { crude }^{\mathrm{a}}\end{array}$ & $\begin{array}{c}\text { Pure } \\
\text { hydrocarbons }\end{array}$ & $\begin{array}{l}\text { Total } \\
\text { crude }^{\mathrm{a}}\end{array}$ & $\begin{array}{c}\text { Pure } \\
\text { hydrocarbons }^{b}\end{array}$ \\
\hline I & $11.3 \pm 0.2$ & $29.2 \pm 0.6$ & $21.3 \pm 1.2$ & $85.3 \pm 4.3$ \\
\hline II & $11.1 \pm 0.3$ & $26.3 \pm 0.5$ & $28.0 \pm 1.5$ & $72.4 \pm 3.7$ \\
\hline III & $6.3 \pm 0.1$ & $26.1 \pm 1.0$ & $24.1 \pm 1.3$ & $65.1 \pm 2.1$ \\
\hline IV & $3.5 \pm 0.1$ & $14.1 \pm 0.3$ & $23.4 \pm 1.8$ & $61.4 \pm 3.5$ \\
\hline $\mathrm{V}$ & 0.0 & 0.0 & $26.2 \pm 1.1$ & $75.1 \pm 2.4$ \\
\hline
\end{tabular}

cycles were dramatically reduced compared with the numbers at the start. This was true for both the biofilmcoated and -uncoated particles. Here too, most of the bacteria were suspended in the water around the uncoated particles, but the biofilm-coated particles still contained much more bacteria than those suspended in the water.

The data in Table 2 confirm that the total oil-utilizing bacteria in each $100 \mathrm{ml}$ seawater batch showed steady decreases during successive cycles of cleaning. In considering the data, it must once again be emphasized that the uncoated gravel particles were almost free from bacteria whereas the biofilm-coated particles always carried more bacteria than those suspended in the water (see Table 1).

In all cases the predominant hydrocarbon-utilizing bacterium was identified as Acinetobacter calcoaceticus; minor bacteria included Micrococcus sp. and nocardioforms. These organisms could grow well on individual $n$-alkanes, ranging from $\mathrm{C}_{9}$ to $\mathrm{C}_{32}$, and aromatic hydrocarbons including polynuclear ones as sole sources of carbon and energy.

Table 3 shows the crude oil and constituent hydrocarbon consumption values in seawater batches successively treated with biofilm-coated and -uncoated gravel particles. The values for the coated particles were obviously much higher than those for the uncoated particles. For the uncoated particles, the highest consumption values were measured at the end of the first and second, and to a lesser degree the third, cycles. After the fourth cycle the consumption values were lowest, and consumption ceased in the fifth cycle. In contrast, the consumption values for the coated particles seemed to remain constant at a rather high level during the successive cycles of cleaning.

This result is also quite clear from the GLC-profiles of the residual pure hydrocarbons presented in Fig. 1.

\section{DISCUSSION}

There is evidence that in the laboratory artificially immobilized hydrocarbon-degrading microorganisms still maintain their hydrocarbon biodegradation potential (Heinrich \& Rehm 1981, El-Assar et al. 1988). In the early 1990s we reported on the first naturally immobilized consortium of hydrocarbon-degrading microorganisms on the Arabian Gulf coasts (Sorkhoh et al. 1992). The consortium consisted of cyanobacterial mats immobilizing large numbers of hydrocarbon degraders. The present paper reports on another novel microbial consortium naturally immobilized on gravel particles along the Gulf coasts. This consortium contributes to the self-cleaning of the coasts and, in addition, could potentially be applied in the purification of oily industrial wastes before their disposal in the open environment.

The immobilization effect is quite apparent from the results in Table 1, which show that biofilm-coated gravel particles retained major proportions of the hydrocarbon-utilizing bacteria after having been shaken in oily sea water. In contrast, uncoated particles, which also were loaded with rather high numbers of hydrocarbon degraders, did not retain any significant numbers of bacteria after having been shaken in oily sea water. The immobilization effect is also clear from the fact that after the first cleaning cycle the number of hydrocar- 


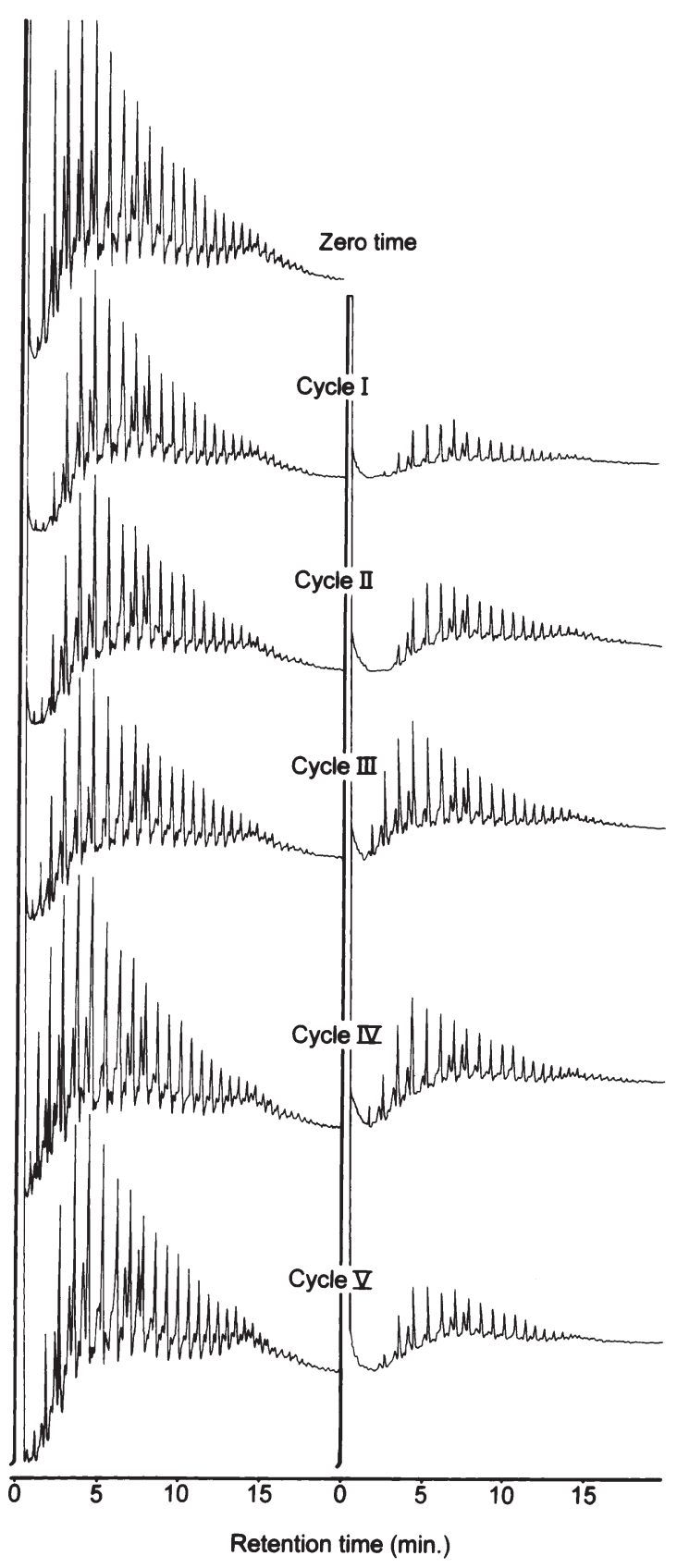

Fig. 1. Typical GLC-profiles of TLC-purified hydrocarbons recovered from 5 oily seawater batches subjected to purification with biomass-coated (right profiles) and -uncoated (left profiles) gravel particles

bon-utilizing bacteria suspended in the water was twice as much in the batch with uncoated particles as in the batch with coated particles (Table 2). It is understandable that the total numbers of hydrocarbon-utilizing bacteria dramatically decreased during successive cycles of cleaning. This is obviously due to the loss of all bacteria, which became suspended in the water of the successive batches that was harvested for analysis.
Even with the coated particles we observed dramatic losses in the suspensions of biomass flocks, obviously associated with huge numbers of hydrocarbon-utilizing bacteria. Nevertheless, the results (Table 1) indicate that the magnitude of that loss was much higher for the uncoated than for the coated particles, which again demonstrates the efficient immobilization effect of the latter. This immobilization effect naturally protects the bacteria from being washed out into the open sea. Another advantage of this immobilized consortium of microorganisms is that the bacteria are in the close vicinity of oxygen-producing phototrophic microorganisms. Oxygen is known to be essential for the initial biochemical reaction during the bacterial attack on hydrocarbons via their oxygenase systems (Jamison et al. 1975, von Wedel et al. 1988, for reviews see Leahy \& Colwell 1990, Radwan \& Sorkhoh 1993).

A promising practical outcome of this study is that the use of such biofilm-coated gravel particles could be suggested for preparing trickling filters similar to those employed in sewage-effluent treatment. Such filters may be applied, in a parallel practice, for cleaning oily liquid wastes before their disposal in the open environment. In such filters, the process of cleaning could be a continuous approach, and the amount of bacterial loss with flocks released from the particles could be minimized.

Acknowledgements. This work was supported by Kuwait University Research Grants SO 071 and SLO 062. The technical assistance by Samar Salamah and Israa El-Nemr is highly appreciated.

\section{LITERATURE CITED}

Al-Hasan RH, Sorkhoh NA, Al-Bader D, Radwan SS (1994) Utilization of hydrocarbons by cyanobacteria from microbial mats on oily coasts of the Gulf. Appl Microbiol Biotechnol 41:615-619

Al-Hasan RH, Al-Bader D, Sorkhoh NA, Radwan SS (1998) Evidence for $n$-alkane consumption and oxidation by filamentous cyanobacteria from oil-contaminated coasts of the Arabian Gulf. Mar Biol 130:521-527

El-Assar SA, Omar SH, Rehm HJ (1988) Oxidation of $n$ tetradecans by Candida parapsilosis KSh 21 adsorbed on different glass rings. Appl Microbiol Biotechnol 29: 442-446

Heinrich M, Rehm HJ (1981) Growth of Fusarium moniliforme on $n$-alkanes: comparison of an immobilization method with conventional process. Eur J Appl Microbiol Biotechnol 11:139-145

Jamison VM, Raymond RL, Hudson JO Jr (1975) Biodegradation of high-octane gasoline in ground water. Dev Ind Microbiol 16:305-312

Kates M (1972) Techniques of lipidology. North Holland Publishing Company, Amsterdam

Leahy JG, Colwell RR (1990) Microbial degradation of hydrocarbons in the environment. Microbiol Rev 54:305-315 
Mangold HK, Malins DC (1960) Fractionation of fats, oils and waxes on thin layers of silicic acid. J Am Oil Chem Soc 37: 383-385

Radwan SS, Sorkhoh NA (1993) Lipids of $n$-alkane-utilizing microorganisms and their application potential. Adv Appl Microbiol 39:29-90

Radwan SS, Al-Hasan RH, Al-Awadhi H, Salamah S, Adbullah HM (1999) Higher oil biodegradation potential at the Arabian Gulf coast than in the water body. Mar Biol 135: 741-745

Sorkhoh NA, Ghannoum MA, Ibrahim AS, Stretton RJ, Rad-

Editorial responsibility: John Dolan,

Villefranche-sur-Mer, France wan SS (1990) Crude oil and hydrocarbon-degrading strains of Rhodococcus rhodochrous isolated from soil and marine environments in Kuwait. Environ Pollut 65:1-17

Sorkhoh NA, Al-Hasan R, Radwan S, Höpner T (1992) Selfcleaning of the gulf. Nature 359:109

von Wedal RJ, Mosquera JF, Goldsmith CD, Hater GR, Wong A, Fox TA, Hunt WT, Paulies MS, Quiros JM, Wiegand JW (1988) Bacterial biodegradation of petroleum hydrocarbons in ground water: in situ augmented bioreclamation with enrichment isolates in California. Water Sci Technol 20:501-503

Submitted: June 20, 2000; Accepted: October 12, 2000

Proofs received from author(s): November 30, 2000 
